\title{
The Determinant of Financial Performance Based on Good Corporate Governance and Company Size in the Basic Industrial and Chemical Sectors 2015-2019
}

\author{
Rifqi Rizqullah* and Johannes Kristian Siregar
}

\author{
Faculty of Economics and Business, Universitas Informatika dan Bisnis Indonesia, Bandung, Indonesia \\ *Corresponding author. Email: rifqiqullah@gmail.com
}

\begin{abstract}
This research aim to provide an overview of the factors that can affect financial performance in basic industrial sector companies and chemicals listed on the Indonesia Stock Exchange for the 2015-2019 periods. The dependent variable is financial performance and the independent variable is Good Corporate Governance (GCG) as peroxide by the Independent Commissioner, and Company Size. All manufacturing companies listed on the IDX in the Basic Industry and Chemical Sector 2015-2019 are the population in this research. This research uses secondary data in the form of financial reports obtained from the official website of the Indonesia Stock Exchange, namely www.idx.co.id, with a sample size of 40 companies taken based on the criteria that have been determined in this research. This research uses purposive sampling technique. The data testing technique is done by using classical assumption, multiple linear regressions, multiple linear correlation, determination coefficient, and hypothesis testing. The results of this study indicate that; GCG has a significant positive effect on the Company's financial performance; The firm size variable has a positive and significant effect on the company's financial performance; GGG and Company Size simultaneously have a positive effect on financial performance.
\end{abstract}

Keywords: Good Corporate Governance, Firm Size, Financial Performance

\section{INTRODUCTION}

The company is divided into several legal entities, one of which is a limited liability company (PT). The limited liability company has three organs of the company, which are directors, Commissioners and RUPS in accordance with agency theory. The agency's theory has a weakness, with the division of tasks that exist as agents and some are principals, can pose a conflict of interest. Agency relationships constitute a contract whereby one or more persons (principals) govern others (agents) to perform a service on behalf of the principal and authorize the agent to make the best decision for the principal. The company's business to maintain sustainability (Going Concern) takes a proper and good management. Company owners will strive to achieve the company's objectives. To achieve the goal set, the owner of the company handed over the management of the company to professional personnel called agents. Agents are given authority in running the operational of the company because the owner believes that the agent is capable and understand in carrying out the operational activities of the company and can achieve the objectives of the company is good financial performance. Financial performance can be analyzed using several indicators such as return on equity (ROE), total sales, and return on asset (ROA). In some indicators for financial performance analysis, ROA is deemed to reflect overall (comprehensive) compared to other indicators.

ROA is the ratio that shows the return on the number of assets used in the company [1]. ROA is also a measure of the effectiveness of management in managing its investments. ROA is also used to measure how much the company is capable of generating a return on an asset to a net profit. If an ROA company is getting bigger it can mean better financial performance [2]. It reflected the 
efficiency, effectiveness, and economy in the company because it has a lot of assets but it generates a net profit that is less good in taste. Conversely, if a company has a number of assets that is not too much but can generate a large enough net profit then the company can be said the financial performance is judged quite well.

Achieving good financial performance and the weakness of agency theory, a system that is structured to ensure the creation of a conducive climate within a company. Good Corporate Governance (GCG) is good corporate governance in GCG so it is regulated how every organ in the company can carry out its tasks, staples, and functions in accordance with the established rules. So expect no Conflict Of Interest in a company. In GCG, there are several components including the Board of Commissioners, institutional ownership, board of Directors, and Audit Committee. The Board of Commissioners is part of the company's organs and has a vital role in the company because the Board of Commissioners as a representative of the principal or owner of the company who is looking to supervise the board of Directors so that the company can achieve its objectives. The Board of Commissioners is tasked with conducting supervision in general and/or specifically in accordance with the Articles of association and advising the directors [3].

The Board of Commissioners itself is divided into independent and dependent Commissioners. The Independent board of Commissioners originating from the external company, while the dependent Board of Commissioners is the Board of Commissioners that originated from the company itself. In performing the duties, principal and function of the Board of Commissioners must act in accordance with the Code of Ethics and conduct GCG principles. However, the conflict of interest will always occur in every entity, therefore the Board of Commissioners is deemed to have a chance of conflict of interest lower than the dependent Board of Commissioners. The independent Board of Commissioners does not have any other interests in the different businesses of the Board of Commissioners rather than independent because he still comes from the company itself. In companies that have more independent board of Commissioners, it is expected to create better and more effective and efficient operational activities of the company. It will cause the company's financial performance to increase and grow up.

Good and improved financial performance will have greater opportunities from companies that have large total assets, compared to fewer assets. The larger the total asset owned by a company will provide a greater opportunity to generate high returns. Total assets are one indicator in the size of the company. So the larger the size of the company the larger the total assets that the company has. In the manufacturing company environment listed on the Indonesia Stock Exchange Basic Industrial and Chemical Sector in 2015-2019, it can be seen the financial performance trends, GCG, and the size of the company.
The company's performance of the basic and chemical industrial sector in 2015-2019 is experiencing fluctuation. The increase and decline of financial performance is reasonable, but in the manufacturing company of basic and chemical industry sector in 20152019 there is a significant increase and decrease is allegedly due to not being implemented GCG and utilization of total assets.

The manufacturing companies of basic and chemical industry sector 2015-2019 increased continuously in the size of the company except the year 2019. This is indicated because the growing assets of manufacturing companies in the base and chemical industries in the period from 2015 until the period 2019 and especially in 2019 there are several factors that cause the company to reduce its total assets, one of which is the impact of pandemic Covid-19 originating from the Chinese state of Wuhan city. But overall from 2015-2019 the size of the company experienced an increase indicated by the increase in the company's total assets.

The increase in the Company's assets is aligned to the size of the company because one of the indicators of the company's size is the logarithmic of total company assets, but the increase in the size of the company is not coupled with the increase in the company's financial performance. In the picture 2 GCG that was proscribed by the Independent Commissioner was increased and there was only a slight decline in 2017, even in 2019 there was a considerable increase. However, the increase in GCG has not been able to cause the financial performance of the company's manufacturing of basic and chemical industry sector in 2015-2019 especially in 2019 is the lowest position of financial performance of 0.12. As for the GCG that is proscribed by the Independent Commissioner, the year 2019 is the highest position of the period 2015-2019.

The increase of independent Commissioners is deemed to further increase the efficiency and effectiveness of the Company's activities to achieve the objectives that have been determined by one of them is good financial performance. Until the year in 2019 with a high enough increase in the Independent Commissioner is to help suppress the financial performance figures so as not to be worse due to the impact of pandemic Covid-19 as well as other factors that interfere with the trade balance.

Some previous resources have shown relevant relationship between good corporate governance (GCG) and company size to financial performance. The results of the research on reff [4] showed that Good corporate Governance and company size were simultaneously influential to the financial performance of registered banking company at IDX in 2010-2014.

The research on ref [5], the board of Directors has an effect on financial performance, the Audit Committee has no effect on financial performance, managerial ownership has no effect on financial performance, institutional ownership affects financial performance, and the size of the company affects financial performance. 
This result is inversely proportional to the research on ref [6], showed that the audit committee has a positive impact on financial performance, the total assets negatively affect financial performance, the proportion of independent board commissioners negatively affect financial performance The inconsistency of the results from previous research above made researchers interested in reresearching topics regarding financial performance. Based on the phenomenon that has been shown and the correlational relationship mentioned above, researchers are interested to do research under the title " The Determinant Of Financial Performance Based On Good Corporate Governance And Company Size In The Basic Industrial And Chemical Sectors 2015-2019",

\section{METHODOLOGY}

In this research the research method used was a quantitative research method with a research approach to associative analysis of causal relationships. Quantitative research methods with a descriptive research approach and associative analysis of causal relationships were chosen, as the research aims to analyze the data obtained from financial statements by describing or describing the collected data so that it can be known to strong the relationship between the variables through hypothesized analysis of the causation between the variables examined. Quantitative methods were chosen because of the problem that the point of study was obvious. In addition, selection of quantative methods due to the research data used by researchers in the form of numbers, then the data will be analyzed using statistical data and aims to test the hypothesis."Quantitative research methods can be interpreted as a research method based on the philosophy of positivism, used to examine specific populations or samples, data collection using research instruments, quantitative data analysis/statistics, with the aim of testing a predetermined hypothesis" [7]

In this research the population used is the entire financial statement manufacturing Company registered in IDX industrial sector base and chemical period 2015-2019, obtained the research observation data a number of 355 financial statements from 71 manufacturing companies registered in IDX industrial sector base and chemical period 2015-2019. The selection of samples in this study was conducted based on nonprobability sampling using the purposive sampling technique. The following criteria and number of samples set through the Purposive sampling method are then used in the study.

The quality of the research results is influenced by two main things, the quality of research instruments, and the quality of data collection. Quality of research instruments with respect to the validity and reusability of the instrument and the quality of data collection in statutes ways used to collect data.
Tabel 1. Sample Determination Criteria

\begin{tabular}{lll}
\hline NO & \multicolumn{1}{c}{ Criteria } & Total \\
\hline & $\begin{array}{l}\text { The annual financial report published by } \\
\text { the manufacturing company listed on the }\end{array}$ & \\
1 & $\begin{array}{l}\text { Indonesia Stock exchange of the basic } \\
\text { industrial sector and chemistry in 2015- }\end{array}$ & 355 \\
& \\
& & \\
& $\begin{array}{l}\text { The availability of annual financial } \\
\text { statements published by manufacturing }\end{array}$ & \\
2 & $\begin{array}{l}\text { companies listed on the Indonesia Stock } \\
\text { exchange of basic industrial sectors and } \\
\text { chemistry in 2015-2019. }\end{array}$ & \\
& The amount of sample data used & 200 \\
\end{tabular}

In research the data source collected is secondary data. Because the data collected is data published by the Indonesia Stock Exchange which is the annual financial report. So the data collected is secondary data instead of primary data. Data collection techniques conducted by the authors with the documentation/literature study is the collection of data in the form of annual financial statements found in the manufacturing company of basic and chemical industry sector is located on the Indonesia Stock Exchange Year 2010-2019 (www.idx.co.id). The data testing technique is conducted with a series of tests: Classical assumption test, double linear regression coefficient test, test coefficient of multiple linear correlations, coefficient of determination test, and hypothesis test.

\subsection{Multiple Linier Regression}

Multiple linear regression tests are performed to gauge whether independent variables affect dependent variables and how large the influence of both variables is. Here is a regression model in the research:

$$
\mathrm{Y}=\mathrm{a}+\mathrm{b} 1 \mathrm{X} 1+\mathrm{b} 2 \mathrm{X} 2+\mathrm{e}
$$

\begin{tabular}{|c|c|}
\hline lote: & \\
\hline $\mathrm{Y}$ & $=$ Financial Performance \\
\hline a & $=$ Constant \\
\hline b1 \& b2 & $=$ Regression Coefficient \\
\hline $\mathrm{X} 1$ & $=$ Good Corporate Governance \\
\hline $\mathrm{X} 2$ & $=$ Firm Size \\
\hline & $=$ Residual $/$ Error \\
\hline
\end{tabular}




\subsection{Correlation Coefficient}

Correlation is the relationship and regression is influence [8]-[10]. The correlation can occur alternating, for example A relates to $\mathrm{B}$ as well as $\mathrm{B}$ in relation to $\mathrm{A}$. For regression is not reversed, meaning an affects $B$, but it should not be said B affects A [7]. The Interpretation guidelines of correlation coefficient can be seen in Table 2 .

Table 2. Interpretation guidelines of correlation coefficient

\begin{tabular}{cc}
\hline Interval Coefficient & Level of relationship \\
\hline $0.00-0.199$ & Very Weak \\
$0.20-0.399$ & Weak \\
$0.40-0.599$ & Medium \\
$0.60-0.799$ & Strong \\
$0.80-1.000$ & Very Strong \\
\hline
\end{tabular}

\subsection{Determination Coefficient}

The correlation analysis can be continued by calculating the coefficient of determination, by the way of thicming the found coefficient [7]. The formula for coefficient of determination is as follows.

$$
\mathrm{KD}=\mathrm{r} 2 \times 100 \%
$$

Information:

$\mathrm{KD}=$ Coefficient of determination

$\mathrm{R}=$ Correlation Coefficient

\subsection{Hypothesis Testing}

Testing of this hypothesis is a stage to make a temporary conclusion in committing the rejection and or justification of the problem to be researched; in order to set the conclusion while then assigned a zero hypothesis and an alternative hypothesis. The testing phase of the research hypothesis is to test whether there is an influence between the independent variables of GCG, company size to the dependent variable of financial performance either partially or simultaneously. The hypothesis testing was conducted using Test $\mathrm{T}$ and test F. Hypothesis testing with the $\mathrm{T}$ test indicates whether or not the influence and significance of the variables of the dependent variable are present. The variable affects when thing > Table and the significance value is $<0.05$. In Test $F$, the independent variable is simultaneously declared to have an effect if the Fhitung > F Table.

\section{RESULTS AND DISCUSSION}

The basic and chemical industry indices are part of a sectorial index categorized by IDX, an index that measures the performance of all stock prices on the main board and Development Board in the basic and chemical industry sectors, referring to the Jakarta Stock Industrial Classification (JASICA) classification. As of 2020, it has 71 classified stocks in the basic and chemical industry indices, where they are classified back into 9 sub-sector categories, among them the cement subsector; Timber and processing subsectors; subsectors of ceramics, porcelain, and glass; Plastic and packaging subsectors; Pulp and paper subsectors; Chemical subsectors; Metal subsectors and the like; Livestock feed subsectors; and other basic industrial and chemical subsectors. The research object is a manufacturing company that is located in the basic and chemical industry sectors listed on the Indonesia Stock exchange for the period of 2015-2019. This population uses secondary data in the form of financial statements obtained from the official website of Indonesia Stock Exchange www.idx.co.id, with a sample number of 40 companies taken in accordance with the research criteria described.

\subsection{Research Result}

\subsubsection{Multiple Linier Regression}

Table 3. Multiple Linier Regression

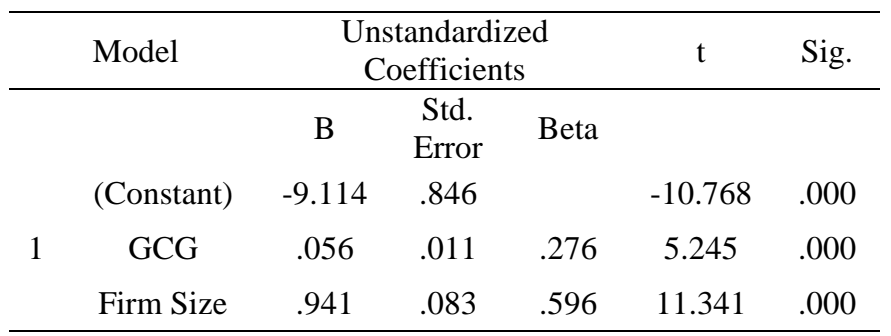

a. Dependent Variable: Financial Performance

Result of data processing as presented in Table 3 then can be formed equation of variable regression applied tax and tunneling incentive against managerial performance as follows:

$$
\mathrm{Y}=-9.114+0.56 \mathrm{X} 1+0.941 \mathrm{X} 2
$$

The regression model in this study can be explained as follows:

1. The value of constants (a) is 9.114. This indicates that if GCG (X1) and company size (X2) is zero The company value is negative, which is 9.114 .

2. The value of a variable regression coefficient of GCG (X1) is positive value, which is 0.056 . This suggests that every increase in financial performance by one unit, the value of the company will increase by 0.056 
assuming another independent variable is fixed in value.

3. Variable regression coefficient of enterprise size (X2) value is positive, which is 0.941 . This indicates that each company's size increases by one unit, hence the value of its enterprise will increase by 0.941 assuming another independent variable is fixed.

\subsection{Correlation Coefficient}

From Table 4, the value of the double correlation coefficient (R) is 0.773 . This figure shows the correlation/the relationship between the GCG variable and the company's size to the company's financial performance. The decision to make strong/weak relationship between the variables is based on Table 4 interpretation guidelines of the correlation coefficient expressed by Sugiyono (2018:184). Based on Table 4 above, it can be concluded that the 0.773 value is included in the 0.60-0,799 interval which means the relationship between GCG and company size to the company's financial performance has a strong level of relationship.

Table 4 Correlation Coefficient

\begin{tabular}{ccccc}
\hline Model & $\mathrm{R}$ & $\begin{array}{c}\mathrm{R} \\
\text { Square }\end{array}$ & $\begin{array}{c}\text { Adjusted } \\
\text { R Square }\end{array}$ & $\begin{array}{c}\text { Std. Error of } \\
\text { the Estimate }\end{array}$ \\
\hline 1 & $.773^{\mathrm{a}}$ & 0.597 & 0.593 & .95861 \\
\hline
\end{tabular}

a. Predictors: (Constant), GCG, Firm Size

b. Dependent Variable: Financial Performance

\subsubsection{Determination Coefficient}

$\mathrm{R}^{2}=\mathrm{R} \times \mathrm{R}$

$\mathrm{R}^{2}=0.773 \times 0.773=0.593$

From the above formula we can know the value of $\left(\mathrm{R}^{2}\right)$ is 0.597. Obtained the value of multiple coefficient of determination $\left(\mathrm{R}^{2}\right)$ of 0.597 or $59.7 \%$. This figure indicates that the donation percentage of the influence of the GCG variable and the company size against the company's financial performance variables is $59.7 \%$, while the remainder is influenced by other variables not included in this research model.

\subsubsection{Hypothesis Testing}

a. T-Test

From Table 6, obtained the calculated t value for each GCG variable and the company size is 5.245 and 11.341 .

Determine Table Sought at significance levels $\frac{0.05}{2}=$ 0.025 (caused 2 sides) with formula:

$$
\begin{aligned}
\mathrm{df} & =(\mathrm{n}-\mathrm{k}-1) \\
& =(199-2-1) \\
& =196 \approx 1.971
\end{aligned}
$$

Because the value of Thitung for the variable GCG and the size of the company respectively is $5.245(5.245>1.971)$ and $11.341(11.341>1.971)$ with a probability of significance smaller than its significance level of 0.000 and 0.000 for each each of the variables $(0.000<0.05)$ and $(0.000<0.05)$ so that based on the hypothesis testing criteria concluded that GCG was partially influential positively on the company's financial performance and the company size was partially influential positively on the company's financial performance.

\section{b. F Test}

The F Table value can be searched from distribution table $\mathrm{F}$ at significance level 0.05 by using formula (See Table 7):

$$
\begin{aligned}
\mathrm{df} & =(\mathrm{n}-\mathrm{k}-1) \\
& =(199-2-1) \\
& =196 \approx 3.04
\end{aligned}
$$

Because the value of Fhitung to be obtained is 145.344 $(145.344>3.04)$ with a probability of significance smaller than the significance level of $0.000(0.000<0.05)$, so based on the criteria of testing hypothesis can be concluded that $\mathrm{H} 0$ rejected and $\mathrm{Ha}$ accepted. It means that simultaneously the GCG and size of the company positively affect the financial performance of the company.

\subsection{Research Discussion}

\subsubsection{The Effect of GCG on Financial Performance}

Based on the results of the test that has been done, the value of $t_{\text {hitung }}$ for the GCG variable is 5.245 (5.245 > $1.971)$ with a probability of significance smaller than the significance level of $0.000(0.000<0.05)$ so that based on the hypothesis testing criteria concluded that GCG has a partial positive effect on the company's financial performance. The results of this research are consistent with the Agency theory and good corporate governance theory that the company performs good corporate governance implementation, one of which has an independent board of Commissioners. 
Table 5 T-Test Result

\begin{tabular}{|c|c|c|c|c|c|c|}
\hline & \multirow[t]{2}{*}{ Model } & \multicolumn{2}{|c|}{$\begin{array}{l}\text { Unstandardized } \\
\text { Coefficients }\end{array}$} & \multirow{2}{*}{$\begin{array}{c}\text { Standardized } \\
\text { Coefficients } \\
\text { Beta }\end{array}$} & \multirow[t]{2}{*}{$\mathrm{t}$} & \multirow[t]{2}{*}{ Sig. } \\
\hline & & B & Std.Error & & & \\
\hline \multirow{3}{*}{1} & (Constant) & -9.114 & .846 & & -10.768 & .000 \\
\hline & GCG & .056 & .011 & .276 & 5.245 & .000 \\
\hline & Firm Size & .941 & .083 & .596 & 11.341 & .000 \\
\hline
\end{tabular}

a. Dependent Variable: Financial Performance

Table 6 F Test Result

\begin{tabular}{llccccc}
\hline \multirow{2}{*}{ Model } & $\begin{array}{c}\text { Sum of } \\
\text { Squares }\end{array}$ & Df & $\begin{array}{c}\text { Mean } \\
\text { Square }\end{array}$ & F & Sig. \\
\hline \multirow{2}{*}{$1 \quad$ Regression } & 267.121 & 2 & 133.561 & 145.344 & $.000 \mathrm{~b}$ \\
& Residual & 180.110 & 196 & .919 & & \\
& Total & 447.232 & 198 & & & \\
\hline
\end{tabular}

a. Dependent Variable: Financial Performance

b. Predictors: (Constant), GCG, Firm Size

\subsubsection{The Effect of Company Size on Financial Performance}

Based on the results of the test that has been done, it can be concluded that the size of the company has a significant positive effect on the company's financial performance in the basic and chemical industry sectors listed on the Indonesia Stock Exchange period 20152019. This is seen from a company size variable thitung value of $11.341(11.341>1.971)$ with a probability of significance smaller than its significance level of 0.028 for the company size variable $(0.000<0.05)$.

\subsubsection{The Effect of GCG and Company Size on Financial Performance}

From the tests that have been done it can be concluded that good corporate governance and the size of the company together have a positive effect on the financial performance of the company. Because the value of Fount obtained is $145.344(145.344>3.04)$ with a probability of significance smaller than the significance level of $0.000(0.000<0.05)$, then it can be concluded that $\mathrm{H} 0$ was rejected and $\mathrm{Ha}$ accepted. This means that gag simultaneously and the size of the company have a positive and significant impact on the company's financial performance.

\section{CONCLUSIONS}

The purpose of this study is to determine the influence of GCG and the size of the company on financial performance in manufacturing companies listed on the Indonesia Stock Exchange in 2015-2019. The results of the research described in the previous chapter, can be found the following conclusions:

1. The GCG variables that are proscribed by independent commissioners have significant positive impact on the company's financial performance. This research is consistent with the Agency theory and good corporate governance theory that the company that performs good corporate governance implementation, one of which has an independent board of Commissioners, will encourage the creation of a conducive working climate and improve financial performance and to avoid the occurrence of conflicts of interest and Agency problem.

2. The size of the company has a significant positive effect on the financial performance of manufacturing companies listed on the Indonesia Stock Exchange, the basic industrial sector and chemical period 20152019.

3. Simultaneously, the GCG and size of the company have a significant positive effect on the financial performance of manufacturing companies listed on the Indonesia Stock Exchange, the basic industrial 
sector and the chemical period of 2015-2019.

4. The coefficient value shows R-squared 0.597 or $59.70 \%$. This figure indicates that the donation percentage of the influence of the GCG variable and the company size against the company's financial performance variables is $59.70 \%$, while the remainder is influenced by other variables not included in this research model.

\section{REFERENCES}

[1] E. Abolfathi, P. Taebi. Modern Analysis of Financial Statements: Pharmaceutical companies in Iran. Journal of management and accounting studies, 8 (2) (2020) 85-97. DOI: https://doi.org/10.24200/jmas.v ol8iss $2 \mathrm{pp} \% 25 \mathrm{p}$

[2] R. A. Kinanti, P. Purwohandoko. Influence of thirdparty funds, Car, NPF and FDR towards the return On assets of Islamic banks in Indonesia. JEMA: Jurnal Ilmiah Bidang Akuntansi dan Manajemen, 14 (2) (2017) 135-143. DOI: http://dx.doi.org/10.31106/jema. v14i02.524

[3] B. Rifai. Peran komisaris independen dalam mewujudkan good corporate governance di perusahaan publik. Jurnal Hukum IUS QUIA IUSTUM, 16 (3) (2009) 396-412. DOI: https://doi.org/10.20885/iustum. vol16.iss3.art5

[4] M. E. S. Santosa, I. P. R. Pradnyana, I. G. C. Putra. Determinants Of Financial Performance Of Banking Companies Registered In Indonesia Stock Exchange. International Journal Of Sustainability, Education, And Global Creative Economic (Ijsegce), 3 (3) (2020) 583-592. DOI: https://doi.org/10.1234/ljsegc e.v3i3.167

[5] P. P. Enda. Pengaruh Penerapan Good Corporate Governance Dan Ukuran Perusahaan Terhadap Kinerja Keuangan Perbankan Yang Terdaftar Di Bursa Efek Indonesia Periode 2013-2016. E-Jurnal Akuntansi, 21 (1) (2017) 310-329. DOI: https://Doi.Org/10.24843/Eja. 2017.V21.I01

[6] S. Magdalena, I. Yuningsih, I. A. Lahaya. Pengaruh Firm Size Dan Good Corporate Governance Serta Corporate Social Responsibility Terhadap Kinerja Keuangan Pada Bank Umum Syariah Di Indonesia. Jurnal Ekonomi Syariah, 5 (2) (2017) 221-238.

[7] Sugiyono, Metodologi Penelitian Kuantitatif, Kualitatif dan R \& D, Bandung: Alfabeta 2018.
[8] J. Jiang, R. Chen, C. Zhang, M. Chen, X. Li, G. Ma. Dynamic Fault Prediction of Power Transformers Based on Lasso Regression and Change Point Detection by Dissolved Gas Analysis. IEEE Transactions on Dielectrics and Electrical Insulation, 27 (6) (2020) 2130-2137. DOI: https://doi.org/10.1109/TDEI.2020.00 8984

[9] W. Jiang, A correlation coefficient for belief functions. International Journal of Approximate Reasoning, 103 (2018) 94-106. DOI: https://doi.org/10. 1016/j.ijar.2018.09.001

[10] S. Boughorbel, F. Jarray, M. El-Anbari. Optimal classifier for imbalanced data using Matthews Correlation Coefficient metric. PloS one, 12 (6) (2017), e0177678. DOI: https://doi.org/10.1371/journal.pone.01 77678 